Универзитет уметности у Београду, Одсек теорија уметности и медија, Београд

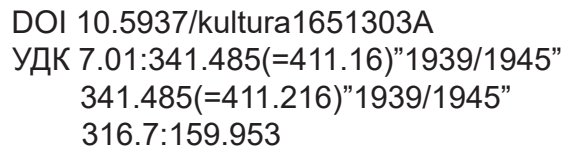

оригиналан нучни рад

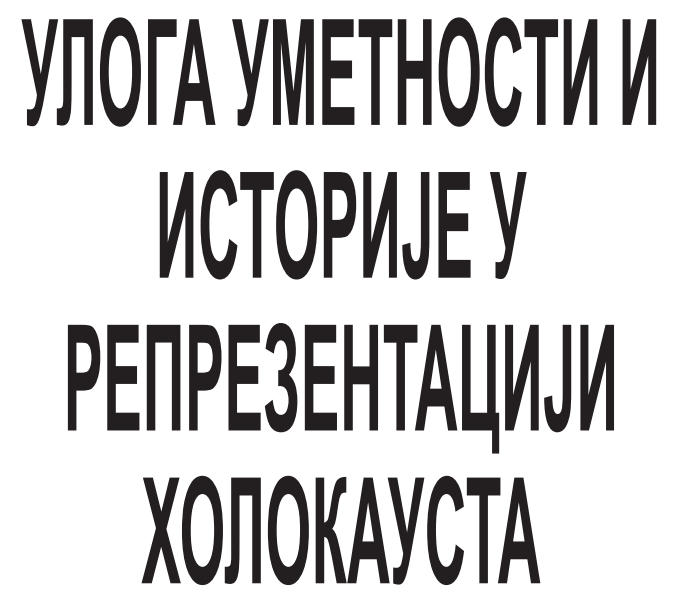

Сажетак: Након чувене Адорнове реченице: ,Писати поезију после Аушвииа је варварство, поставља се питање да ли је етички представљати холокауст у уметности и ако јесте, на који начин је то могуће учинити. Дискурс холокауста мотивисао је и покренуо бројне уметнике и критичаре на промишљање и дискусију о неразјашьеним питањима репрезентације холокауста: Ко има право да покуша да представи холокауст? Како треба представљати холокауст и како се можемо бавити питањем одговорности у послератном свету? Поезија, ритуал, музика, филм, фотографија, уметност уопште, помажу нам да се сетимо, подсећају оне који се нису чак ни родили да морају да осете патюу коју су имали среће да избегну, не само зарад одавања почасти жртвама, већ да би и сами остали хумани. У Аушвииу су култура, наука, уметност, прогрес постали наказне слике у огледалу ьудског бивствовања. Питање које се стално постављ п пред нама после Аушвииа је: Да ли је Аушвии крај-врхунаи наше културе, или је прекретница коју још нисмо разумели? Да ли је могућа уметност која ће изразити истину о Аушвицу? Ако холокауст означава историјски преокрет због примене екстремног насиьа масовног убијања, онда тај преокрет поставља пред индивидуално сећање и колективно памћење сасвим нове изазове.

Кључне речи: холокауст, траума, сећање, памћење, уметност, uсторија 


\section{$У_{6 о \partial}$}

Рад се бави тренутно врло актуелним питањем холокауста, улогом и одговорношћу историчара и уметника у тумачењу и интерпретацији „Шое” (Shoah) ${ }^{1}$, и појма колективне трауме генерално узев. У раду се анализирају савремене теорије трауме, социоконструктивистичке теорије памћења, као и однос индивидуалног и колективног сећања и памћења. Теза од које полазим јесте да уметност холокауста чува свест и негује успомену на цивилизацијску трауму како се она никада више не би поновила. Стога ћу кроз рад посматрати и одговорити на питања о значају уметности холокауста на даљи развој човечанства. Уметност као последња одступница замишљеног отпора варваризму представља преносни механизам у процесу памћења, разоткривања и тумачења историје холокауста. Тражећи смисао тамо где смисла нема, уметност опомиње и држи сећање на холокауст живим. У том смислу, спознајни карактер уметности постаје сведоком истине, истине која не сме бити заборављена и промењена.

\section{Дистинкиија и диференщијачија појмова nамћене/сећане}

И памћење и сећање су начини концептуализације времена јер је време нешто што се једино не може вратити. У памћењу и сећању прошлост није мртва и у томе леже могућности манипулације. Сећање се односи на нашу визију прошлости и оно је увек актуелна творба смисла, не значења. Чим се сећамо, ми тумачимо. Сећања не постоје као затворени системи, него се у друштвеној реалности увек дотичу, појачавају, укрштају, модификују, поларизују с другим сећањима и импулсима заборава. ${ }^{2}$ Крећући се у пољу између активности и пасивности, сећања преиначују и реконструишу прошлост, она су неухватљива, динамична и флексибилна.

1 Јевреји радије користе библијски термин Шоа (האושה, Shoah) који значи несрећа, катастрофа, уништење. Реч Холокауст изворно је грчка реч Холокаустон, а састављена је од холос (сав) и каустос (спалити). У античкој Грчкој овај појам означавао је религиозни обред у ком се животиња ритуално спаљивала и, као жртва, приносила богу. На латински се реч преводи са holocaustum, а први пут се спомиње у хроникама Роџера од Хоудена (Roger of Howden) и Ричарда од Девизеа (Richard of Devizes) из 1190.године који извештавају о масакрима почињеним над Јеврејима. Иако је раније ова реч коришћена за све велике масакре, од Другог светског рата термин холокауст односи се искључиво на геноцид над Јеврејима у ком је животе изгубило више од шест милиона људи. Ипак, због увредљиве природе речи холокауст која се везује за старогрчки пагански обичај, Јевреји радије користе библијски термин Шоа (האושה,Shoah).

2 Assmann, J. and Czaplicka, J. (1995) Collective Memory and Cultural Identity, New German Critique, No.65, New German Critique: Cultural History/ Cultural Studies (Spring-Summer 1995), p. 125-133. 
Сећања су подложна утицајима, а ми треба да разумемо како се обликују и ко их обликује. ${ }^{3}$ Култура сећања, односно политика културе сећања је стратегија, идеолошки конструкт који одређује које прошлости се сећамо и како. За разлику од сећања које представља активизацију на индивидуалној бази, памћење је процес складиштења и сортирања информација и разликује се од перцепције и имагинације. Фројдова (Sigmund Freud) психоанализа заснива се на домену психопатологије памћења. Психоанализа притом представља скуп стратегија где се магловита, потиснута сећања враћају у свесно и освешћено. Кроз психоанализу преко памћења покушавамо да допремо до сећања путем дедукције трагова сећања, слично декодирању знакова болести и поремећаjа. Потиснуто лично сећање је траума - руптура, или пробој, успостављање дисконтинуитета док културна траума у историјском смислу означава руптуру у културној пракси. Званично цензурисање прошлости је итекако добро познато и намеће питања: „Могу ли групе, као што то чине појединци, да потискују оно што је неугодно за памћење? И ако могу, како то чине?"4

Француски социолог Морис Албваш (Maurice Halbwach) 1924. године започиње истраживање памћења изван биолошког склопа, као културну чињеницу. У диркемовском оквиру Албваш је, за разлику од Марсела Пруста (Marcel Proust) тврдио да се прошлост у памћењу не задржава него реконструише, а насупрот Фројду и Јунгу (Carl Gustav Jung), да памћење није резултат несвесног него међуљудског општења. Због тога хајделбершки египтолог Јан Асман (Jan Assmann) изричито твди да је Албваш развио друштвену теорију памћења и учинио је прворазредном међугранском темом. Ова оцена није претерана упркос томе што постоји упадљив временски јаз између настанка Албвашове теорије и њене актуелизације 1980-их година. ${ }^{5}$

\section{Индивидуално сећање $и$ колективно памћене}

Индивидуално сећање може се превести у колективно памћење које добија преносив облик. Доминантна перспектива у истраживању памћења данас је везана за питање о прошлости као конструкцији коју људи развијају према потребама

3 Berk, P. (1999) Istorija kao društveno pamćenje, Reč: Časopis za književnost i kulturu, i društvena pitanja br. 56, Beograd: Radio B92, str. 85.

4 Исто, стр. 91.

5 Kuljić, T. (2006) Kultura sećanja: teorijska objašnjenja upotrebe prošlosti, Beograd: Čigoja, str. 38. 
и могућностима своје актуелне стварности. Друштво цепа или хомогенизује памћење појединаца, а прву системску дезинтеграцију колективног памћења и његову фрагментизацију подстакао је капитализам раслојавањем друштва на низ група у које су појединци уклопљени. Албваш је истакао вишеструкост друштвених времена која сапостоје јер их стварају разне групе: религија, класа, породица, генерациja. ${ }^{6}$ Појединац негује ону слику прошлости коју му намеће група. Слика прошлости тумачи се из перспективе конкретног групног оквира, али и спремности да се одређена слика прихвати. Памћење прекретничких дешавања као на пример Другог светског рата не може се тумачити ван склопа послератног развоја након 1945. године који је био различит у разним срединама. Службено, приватно и лично сећање на фашизам зависе од склопа осмишљавања антифашизма, односно од интереса групе. Први задатак историје памћења је историзација памћења. Тек када се јасно распознају мотиви реконструкције прошлости, може се прићи њеној објективној оцени. Крајем 20. века Албвашову теорију највише су развили немачки египтолог Асман и француски историчар Пјер Нора (Pierre Nora). Памћење није само садржај него и делатност репродуковања ранијих доживљаја. То је сећање саображено новим околностима. Успомена се ствара на сећању, она репродукује и мења сећања. По Албвашу, успомена је унутрашњи простор који се шири у процесу социјализације. Простор је скуп симболичких и вербалних конвенција. Сећамо се само онога чему у садашњости можемо створити оквир. Успомена се разликује од традиције и историјске свести. Традиција је обликовање сећања. Тек тамо где прошлост више не подсећа, или се не живи, почиње историја. Албвашова теорија је у средишту послехладноратовске социологије сазнања. Док је у хладном рату критика идеологије била незаобилазан приступ социологије сазнања, Албваш је оживљен и стога што је код њега овај приступ неутрализован или сведен на најмању меру. У први план је избило истраживање друштвене условљености слике о прошлости, а не толико њена употреба у сврхе владања. Премда полази од сличних премиса, класична критика идеологије, којој припада и марксистички правац, не пита се толико о различитој групној условљености, већ пре свега о оној која је у служби владања и подвлашћивања. Слом идеологизоване слике историје с обе стране гвоздене завесе заменила је нова опседнутост памћењем крајем 20. века; с једне стране нестанак ауторитарног памћења, а с друге опсесија

6 Albvaš, M. (1999) Kolektivno i istorijsko pamćenje, Reč: Časopis za književnost i kulturu, i društvena pitanja, br. 56, Beograd: Radio B92, str. 64. 
памћењем, епидемија комеморација и трагања за пореклом, потреба за идентитетом.

Послехладноратовску ситуацију карактерише стварање надтериторијалног глобалног памћења у ком се мањине боре за властито памћење потискујући ауторитарно памћење доминантне културе, експанзија разноликих групних памћења, демократизација и денационализација и нови облик политизације памћења. Диркемовски социологизам је тек након слома хладног рата створио алтернативу с једне стране ранкеовском историзму, а с друге социјалној историји и марксизму. То што је шире прихватање теорије о колективном памћењу релативисало класично схватање објективности историјског сазнања, свакако није резултат унутарнаучног сазревања. Утисак је да се немачка историографија овом процесу и данас више опире од француске. Од унутарнаучних чинилаца Албвашова теорија је изабрана као најприкладнији оквир конструктивистичке историографије и социологије сазнања. Није се променила само слика историје, него и памћења. Културно памћење је постало актуелно. ${ }^{7}$ У различитој мери конструктивистички модификовано диркемовство оснажило је историјски релативизам и активистичко поимање колективног памћења. У 'пост-трауматском веку', у којем се данас налазимо, пракса сећања и теорија сећања тесно су испреплетене. Ми такорећи посматрамо себе док се сећамо. Индивидуално и колективно сећање све се мање схватају као спонтани, природни или сакросанктни чинови, а све више као социјалне и културне конструкције, које се временом мењају и имају властиту историју. ${ }^{8}$

\section{Улога историје $y$ репрезентацији холокауста}

Још од времена класичне антике до ренесансе, значај свега чега човек жели да се сећа повезиван је са упечатљивим сликама (Art of memory). Претражујући шокантна сведочанства преживелих, визуелне слике, бројну документацију, историчари су имали задатак да поново преиспитају немачку историју 20. века. Тражећи смисао догађаја који су довели до рата, желели су да продубе разумевање њиховог ширег политичког и хуманитарног контекста и да предложе теорије о томе зашто је историја остала неразоткривена. Историја

7 Niethammer, L. (2000) Kollektive Identität: Heimliche Qellen einer unheimlichen Konjunktur, Reinbek bei Hamburg: Rowohlt Taschenbuch Verlag, p. 363.

8 Assmann, A. (2011) Cultural memory and early civilization: writing, remembrance, and political imagination, New York: Cambridge University Press, p. 404. 
би, по Берковим (Peter Burke) речима, требало да буде „подсетник", чувар сећања на јавне догађаје који се записују да би се прославили њихови актери, а и зарад потомства, које треба да учи на њиховом примеру. ${ }^{9}$ Према речима теоретичара холокауста Саула Фридлендера (Saul Friedlander), изазови са којима се сусреће историчар холокауста укључују објективност, упрошћавање прошлости и превазилажење дихотомије између недокучиве апстракције милиона мртвих и личне трагедије живота и смрти за време масовних истребљења током холокауста. ${ }^{10}$ Говорећи о емоционалном изазову, ово истраживање показује, како је написао Фридлендер:

„Највећи проблем за историчара Шоа, када је суочен са одјецима трауматичне прошлости, јесте да задржи одређени степен равнотеже између емоција које се изнова пробијају у “заштитни штит”. У ствари, сваки ефекат дистанцирања или интелектуалног рада на Шои је неизбежан и неопходан, а поновна појава јаког емотивног утицаја је често непредвидива и неопходна." 11

На пример, рад историчара у оквиру музеја холокауста даје им прилику да трагају за равнотежом. Холокауст архиви и музеји постоје широм света да би образовали људе о прошлости која никада не сме бити заборављена ни поречена. Места попут европских јеврејских гета у Прагу, Терезину, Варшави и концентрациони логори смрти у Аушвицу, Берген Белзену, Дахау ${ }^{12}$ данас постоје као музеји који служе као спомен обележја од историјског значаја. ${ }^{13}$ Делом, музеји настоје да представе историју колективних и индивидуалних

9 Berk, P. (1999) Istorija kao društveno pamćenje, Reč: Časopis za književnost $i$ kulturu, i društvena pitanja, br. 56, Beograd: Radio B92, str. 83.

10 Friedlander, S. (2000) Facing the Shoah: Memory and History, Humanity at the Limit: The Impact of the Holocaust Experience on Jews and Christians, ed. Signer, M. A. Bloomington and Indianapolis: Indiana University Press, p. 10.

11 Исто.

12 Од 1933. до 1936. године нацистички концентрациони логори (Konzentrationslager) коришћени су углавном за политичке затворенике. Од 1936. до 1942. и остали затвореници су слати тамо и експлоатисани као радна снага. Време од 1942. до 1945. су најгоре године у логору, године смрти, болести, гладовања, претрпаности и нехигијенских услова. Логори смрти нису више радни логори већ центри за систематско убијање као део Хитлеровог коначног решења. Аушвиц, настао 1940. године, састојао се из логора смрти Биркенау (Аушвиц II), као и Буна (Аушвиц III) и других делова логора.

13 Хитлер је такође имао планове за музеј у Прагу „посвећен истребљену Јевреја". Срећом, савезничке трупе су победиле Немачку и онемогућиле остварење његових планова. Видети: LaCapra, D. (1994) Representing the Holocaust: History, Theory, and Trauma, Ithaca and London: Cornell University Press, p. 210. 
судбина. У музеју Аушвиц-Биркенау посетиоци су суочени са екранима предмета који су некада припадали милионима људи који су тамо настрадали. Ако неко одлучи да посети такво место, може очекивати да ће бити преплављен моћним експонатима који сведоче у име страшних злочина.

\section{Уметност као преносни механизам памћена}

Попут историчара, уметници који траже разумевање и значење у трауматичним догађајима, креирају радове како би такви догађаји остали запамћени. Иако су и историчар и уметник мотивисани снажним осећајем одговорности да посведоче таквом људском злоделу, изазов за уметника је да у естетски оквир уметничког дела угради емотивну истину у комбинацији са чињеницама догађаја. Теодор Адорно (Theodor Adorno), један од највећих филозофа и естетичара музике 20. века каже како су нацистичке партије уништиле многе уметнике и интелектуалце и ставиле све културне активности у службу тоталитарног система. Године 1949. Адорно је написао: „Писати поезију после Аушвица је варварство" 14 и критиковао Шенбергову композицију A Survivor from Warsaw, оп. 46 (1947) за сувише директно суочавање са темом. Адорнова накнадна симптоматологија препознаје и сам тај исказ као самосвест застоја, као сазнање које је и само нагрижено оним разлогом због кога је постало неумесно писати песме. Песме су ту друго име за творевине духа, а не за еснафску работу, која би на битно другачији, па чак и „еклатантнији” начин од своје сабраће по роду, музике на пример, западала у невоље и трпела искушења једног трагичног историјског дешавања. ${ }^{15}$ Али седамнаест година касније, 1966. године, Адорно је променио мишљење и напиcaо: „Трајна патња има исто толико права на израз као што онај кога муче мора да вришти; стога је можда била погрешна (моја тврдња) да се после Аушвица песме више не могу писати." ${ }^{16}$ Неке од његових коначних изјава на тему стварања уметности након геноцида подржале су улогу уметности: „Међутим, иако слаба и оптуживана, уметност остаје једна од последњих тачака замишљеног отпора варваризму". ${ }^{17}$ Адорно је, такође, рекао да уметност после холокауста више

14 Adorno, T. Cultural Criticism and Society, in: Prismus, eds. Weber, S. and S. (1981) Cambridge, MA: The MIT Press, p. 34.

15 Krstić, P. (2006) Kritička teorija i holokaust, Filozofija i društvo, 1:37-77, Beograd: Institut za filozofiju i društvenu teoriju, str. 43.

16 Ray, G. (2005) From Auschwitz to Hiroshima to September 11, New York: Palgrave, p. 66.

17 Исто, стр. 130. 
никада неће бити иста. Стога је охрабрио уметнике и друге људе да савесно чувају и негују сећање и свест о жртвама холокауста. Памћење које се, рецимо, одсликава у меморијалним композицијама савремених композитора који су и сами били жртве холокауста може се посматрати двоструко, са аспекта личног сећања и колективног сећања.

За време и након Другог светског рата бројни композитори попут Пендерецког (Krzysztof Penderecki), Шенберга (Arnold Schoenberg), Рут Фазал (Ruth Fazal) и других, писали су политички ангажована дела као одговор на претње фашизма. Захваљујући експресивности коју музичка композиција као форма носи и бројним музичким елементима употребљеним у служби дочаравања места, времена и емоција, музика је, поред других уметности, идеалан медијум за приказ памћења Шое. Чувени ораторијум Пендерецког Dies Irae (познат и као Аушвии Oраторијум), настао у другој фази његовог стваралаштва (1962-1974) представља једну од најзначајнијих меморијалних композиција насталих у знак сећања на холокауст. Први пут су Краковска филхармонија и хор извели композицију 6. априла 1967. године на отварању спомен обележја жртвама фашизма у Аушвицу-Биркенау. Пендерецки је рођен у Пољској, недалеко од Аушвица и имао је само шест година када су Немци 1939. године напали Пољску. Као врло млад био је суочен са страхом и турбулентним догађајима које су задесиле његову земљу. Описујући његово детињство музиколог Волфрам Швингер (Wolfram Schwinger) је написао: „Са прозора своје куће, скривен иза завесе, гледајући и слушајући Јевреје које су одводили није могао да им помогне". ${ }^{18}$ Међутим, иако немоћан у том тренутку, та слика, дубоко урезана у његово сећање, обликовала је касније изразито интензивну партитуру, пуну емотивног набоја. Композитор је свој ораторијум Dies Irae описао као „веома моћно и драматично музичко призивање хорора, патње, бола и људске изопачености које су нацисти нанели својим жртвама". ${ }^{19}$ Као што је Адорно схватио, људи често кроз уметност траже смисао ванредних околности. Многа истраживања холокауста о улози музике настале у концентрационим логорима и гетима, или у послератном периоду, фокусирају се на комплексним социолошким, психолошким и политичким истраживањима. Како уметност буди емоције и враћа сећања на преживљену трауму, питања су којима ћу се бавити у даљем току рада.

18 Schwinger, W. (1989) Krzysztof Penderecki: His Life and Work, London: Schott \& Co. Ltd, p.16.

19 Penderecki, K. (1998) Labyrinth of Time: Five Addresses for the End of the Millenium, Chapel Hill: Hinshaw Music, Inc, p. 95. 


\section{Однос уметности и савремених теорија трауме}

Појам трауме је у последње две деценије заинтересовао бројне књижевне и културалне теоретичаре. Један од преовлађујућих праваца проучавања трауме истиче као основни елемент њену неопозиву неприказивост која измиче свакој интерпретацији. Уз овакву концепцију, један број теоретичара је трауми доделио положај преломног догађаја неке културе. Теоретичари попут Фарела (Kirby Farell), Бергера (James Berger) и Баера (Ulrich Baer) пажљиво одвајају клиничке и терапеутске аспекте траума од императива њене репрезентације и интерпретације не би ли на тај начин нагласили да је појединачна траума пре свега укључена у начине којима се приказује у неком друштву. Тако интерпретација и репрезентација, као друштвени симболички чинови, поново постају важни аспекти разумевања трауме.

Полазећи од те идеје, амерички културални теоретичар Кирби Фарел каже да повреда (рана) захтева интерпретацију, користећи при том израз injury како би нагласио испреплетеност психофизичког бола с наношењем неправде у правном смислу. ${ }^{20}$ Према Фарелу, траума је клинички концепт који се односи на искуство повреде/ране/оштећења (injury) и културални троп који формира тумачење као начин ношења с траумом кроз процес њене симболичке интерпретациje. Појам трауме, према Фарелу, не ограничава се на њене клиничке аспекте, већ њима овладава тако што се додељује положај фигуре (траума као културални троп) нечему што се отима било каквој фигурацији (траума као клинички концепт). Тиме трауматски доживљај услед свог преображаја у фигуру постаје саставни део појединачног психичког или колективног друштвеног механизма који потреса.

Према Бергеру, култура на трауму одговара тако што је заодева у лик апокалипсе како би се могао прихватити неподношљиви ужас историјског догађаја, који се пак у апокалиптичном смислу из трагедије претвара у есхатон. Тиме траума као апокалиптично-есхатолошки догађај у својој разорној бити садржи и крај и обнову света. Догађај који се не уклапа у замисао о континуитету историје не може се објаснити ничим до тада познатим па се проглашава граничним јер прелама историју на време пре и време после ње. Међутим, Бергер тврди да се историја не замишља само из апокалиптичке перспективе неизбежности трауматског догађаја, већ

20 Farrell, K. (1998) Post-traumatic Culture, Injury and Interpretation in the Nineties, Baltimore: The Johns Hopkins University Press, p. 7. 
и из перспективе да се он могао избећи, да није био нужан. Апокалипса из накнадне перспективе тумачи догађаје који су претходили крају, који су најавили крај, а чији знакови нису били препознати. Постапокалипса узима те наводне наговештаје као прилике у којима се могла избећи траума. Као што је био случај и са Фареловом посттрауматском културом, тако и Бергерова концепција постапокалипсе подразумева преображај трауме у општи оквир који омогућава и покреће њену интерпретацију.

Баер показује да није више траума оно што се отима репрезентацији, већ се, напротив, управо њена репрезентација не уклапа у интерпретативни оквир тумача. Фотографије трауме према Баеру наводе онога ко гледа да проживи догађаје који се не поклапају са целином којој припада њихова тачка гледишта. Гледалац освешћује аутоматизовану склоност према придруживању призора већим целинама из којих се обликује смисао. Стога наспрам историје као континуираног протока времена, фотографија представља историју дисконтинуираних, изненадних и неочекиваних догађаја. Баер у напуштању наративног модела времена налази етички потенцијал, јер фотографија гледаоца излаже погледу другог који не живи у сигурности континуираних и каузалних секвенци. Он стога фотографији придаје потенцијал репрезентације историјске трауме: „Фотографија може сачувати гелер трауматског времена". ${ }^{21}$ Према Баеру репрезентацијски потенцијал фотографије лежи у томе што гледаоца суочава с доживљајем који не може постати део његовог искуства. Међутим, на тај начин фотографија и самог гледаоца излаже насиљу. Прво, Баер повлачи паралелу између структуре трауме и технологије фотографисања. Догађај који је повезан с траумом није прорађен у тренутку кад се догодио, он накнадно опседа жртву. Али таква фотографија сада може било ког гледаоца да подвргне узнемирујућем доживљају и изложи га трауматском дејству догађаја с којим није био у додиру. Друго, траума зауставља уобичајени психички процес блокирајући пребацивање доживљаја у сећање. Баерова је теза да и фотографија располаже аспектима особе, стања, догађаја или предмета који су измакли свесној перцепцији у чину фотографисања те не припадају сећању. Као што се трауматски догађај открива накнадно, тако и негатив фотографије чува оне аспекте свог предмета који су видљиви тек каснијим посматрањем фотографије.

21 Baer, U. (2002) Spectral evidence: The Photography of Trauma, Cambridge: The MIT Press, p. 7. 
Фарел, Бергер и Баер заговарају надомештање немогућности заступања траума као несводивог искуства жртве кроз репрезентацијско насиље коме се излаже посматрач. Будући да је траума другог неприказива, репрезентација више не приказује трауму него расцеп између посматрача и жртве. ${ }^{22}$ Стога се концепције посттрауматске и постапокалиптичке културе, те фотографије као механизма овладавања траумом темеље на трансформацији трауме у културални троп. Овај троп ЛаКапра (Dominick LaCapra) ${ }^{23}$ назива културом ране (wound culture) која подразумева да је „свако на неки начин жртва". ${ }^{24}$

Крајем 19. и почетком 20. века, Фројд је писао о теорији трауме у својим делима Remembering, Repeating and WorkingThrough ${ }^{25}$, Mourning and Melancholia ${ }^{26}$ и Beyond the Pleasure Principle ${ }^{27}$. У овим делима Фројд је истакао значај рада кроз трауму, који дозвољава субјекту да прихвати одређене потиснуте садржаје и ослободи се механизма компулзивног понављања. Уметност, тако, не ствара стуацију која гледаоца неодбрањиво преплављује трауматским доживљајима, нити пак може створити одбрану против њих развијајући стрепњу која доводи у стање приправности. Па ипак ако се размотре нијансе које, према Фројду, одлучујуће деле страх и стрепњу, могу се уочити сличности између трауматске неурозе и уметности. Док стрепња садржи димензију „очекивања опасности и припремања на опасност, чак и када она није позната" ${ }^{28}$, страх се односи на „стање у које човек доспева кад се нађе у опасности на коју није био припремљен, при чему нагласак лежи на моменту изненађења. ${ }^{29}$

Уметност са стрепњом дели непознатост догађаја, али се од ње разликује по томе што у уметности изостаје припремљеност на такав догађај. Другим речима, уметност са траумом дели изненадност и неочекиваност, шок догађаја.

22 Caruth, C. (1996) Unclaimed Experience: Trauma, Narrative and History, Baltimore: The John Hopkins University Press.

23 LaCapra, D. (2001) Writing History, Writing Trauma, Baltimore: John Hopkins University Press

24 Исто, стр. 77.

25 Freud, S. Remembering, Repeating and Working-Through, Mourning and Melancholia, Beyond the Pleasure Principle, The Standard Edition of the Complete Psychological Works of Sigmund Freud: vols. 12, 14, and 18, Translated by Strachney, J. (1953), London: Hogarth Press, p. 74.

26 Исто.

27 Исто.

28 Freud, S. (1920/1986) S onu stranu načela ugode, Budućnost jedne iluzije, Zagreb: Naprijed, str. 140.

29 Исто. 
Како Фројд на крају закључује: „Ново ће увек бити услов ужитка". Али, та неприпремљеност на шок не узрокује болест и не доводи у стање стрепње, него, напротив, утиске у којима гледалац" (...) чак врхунски може уживати”. Иако уметност истовремено садржи и димензију припремљености и димензију изненађења, она се не може изједначити ни са стрепњом, ни са страхом. ${ }^{30}$

Као што психоаналитичар жртвује своју дистанцираност и неуплетеност на којима заснива интерпретацију у име властитости и јединствености болесниковог искуства, тако и уметност која омогућава ужитак у шоку не може заступати аутентичност трауматског доживљаја. Оно што недостаје уметности у приказу трауме је то што она не везује (не ствара психичку фиксираност) за доживљај који приказује, ма како он био болан. Међутим, није ли управо та непоновљивост и јединственост искуства трауме оно што она дели с уметношћу? Не придаје ли Фројд трауми кроз обележја јединствености заправо карактер уметничког дела? Траума се не може доживети кроз понављање, већ само ако се очува њен непоновљив карактер; као што и уметност доводи у стање непоновљивог доживљаја. Ако уметност омогућава „врхунски” ужитак у стравичним догађајима, тада гледалац за те догађаје ни на који начин није емотивно везан. Уместо разорног фиксирања за доживљај, гледалац ужива у њему. Уместо да га запрепасти неочекиваност неког расплета, гледалац ужива у чињеници да је био изненађен и да су се догађаји развијали мимо његових очекивања. Управо та избаченост из очекиваног гарантује спознајни увид уметности. Гледаоци се за приказане догађаје везују само док су они нови, а нови су само приликом њиховог првог извођења. Ако се уметност од трауме разликује по томе што подстиче уживање у болним доживљајима, од стрепње се разликује утолико што задржава моменат изненађења. Стога ако уметност не може прикладно да прикаже трауму, она с друге стране проблематизује стрепњу и страх тако што код стрепње одбацује део који штити, док из страха уклања димензију која разара психу.

30 Као што упозорава Лејс (Ruth Leys), Фројд уводи два супарничка поимања репрезентације: једно које се одређује као „репрезентацијска театричност" у којој се субјект дистанцира од трауматског доживљаја, а други у терминима афективног опонашања које упија жртву у трауматски сценарио. Види: Leys, R. (2000) Trauma: A Genealogy, Chicago: University of Chicago Press. p. 275. 


\section{Закључак}

Разматрајући питања могу ли се уметничка дела посматрати као врста уточишта пред радикалним преображајем субјективности коју покрећу трауматски догађаји у друштвеној и историјској стварности спровела сам анализу полазећи од социоконструктивистичких теорија памћења, савремених теорија трауме и Фројдовог тумачења уметности као аналогије за тумачење трауме. Синтеза ових разматрања показује да траума има преломну улогу само ако се друштвена и историјска стварност схвате као довршене и целовите. Описујући неописиво, недокучиво и невероватно уметност холокауста доноси велику тежину гледаоцима. Комуникација са масом уметност поставља на прву раван саопштавања неподобних садржаја стварности учествујући тако у унутрашњој борби гледаоца у проналажењу излаза из морално неприлагођених личних постулата. Као у пауковој мрежи, свака идеја о новом холокаусту дубоко је ухваћена нитима које је вешто и снажно обухватио цео опус који нам је уметност холокауста са великом горчином изнела. Обухваћен незаборавом, холокауст дубоко позициониран у колективној свести човечанства вапи за својом непоновљивошћу. Стога је одговор на питање да ли на уметност холокауста утиче дискурс времена јасан.

\section{ЛИТЕРАТУРА:}

Adorno, T. and Horkheimer, M. (1946/1974) Dijalektika prosvjetiteljstva, Sarajevo: Veselin Masleša.

Adorno, T. Cultural Criticism and Society, in: Prismus, eds. Weber, S. and S. (1981) Cambridge, MA: The MIT Press.

Adorno, T. (1968) Filozofija nove muzike, Beograd: Nolit.

Agamben, G. (1994/1999) The Man Without Content, Stanford:

Stanford University Press.

Agamben, G. (1978/2007) Infancy and History: On the Destruction of Experience, London: Verso.

Albvaš, M. (1999) Kolektivno i istorijsko pamćenje, Reč: Časopis za književnost $i$ kulturu, i društvena pitanja, br. 56, Beograd: Radio B92, str. 63-82.

Altiser, L. (2009) Ideologija i državni ideološki aparati (beleške za istraživanje), Beograd: Karpos.

Arent, H. (2000) Ajhman u Jerusalimu, Reč: Časopis za književnost $i$ kulturu, i društvena pitanja, br. 57, Beograd: Radio B92, str. 37-44.

Asman, A. (1999) O metaforici sećanja, Reč: Časopis za književnost $i$ kulturu, i društvena pitanja, br. 56, Beograd: Radio B92, str. 121-133. 
Assmann, J. and Czaplicka, J. (1995) Collective Memory and Cultural Identity, New German Critique, No. 65, New German Critique: Cultural History/Cultural Studies (Spring-Summer 1995), p. 125-133.

Assmann, A. (2011) Cultural memory and early civilization: writing, remembrance, and political imagination, New York: Cambridge University Press.

Baer, U. (2002) Spectral evidence: The Photography of Trauma, Cambridge: The MIT Press.

Benjamin, W. (1931/1986) Mala povijest fotografije, Estetički ogledi, (Prevele Truda Stamać i Snješka Knežević), Zagreb: Školska knjiga.

Berger, J. (1999) After the End: Representation of Post-apocalypse, Minneapolis: University of Minnesota Press.

Berk, P. (1999) Istorija kao društveno pamćenje, Reč: Časopis za književnost i kulturu, i društvena pitanja, br. 56, Beograd: Radio B92, str. 83-92.

Caruth, C. (1996) Unclaimed Experience: Trauma, Narrative and History, Baltimore: The John Hopkins University Press.

Caygill, H. (1998) Walter Benjamin: The Colour of Experience, London: Routledge.

Daković, N. Remembrances of the Past and the Present, History of the Literary Cultures of East-Central Europe. Junctures and disjunctures in the $19^{\text {th }}$ and $20^{\text {th }}$ centuries. Volume 4: Types and stereotypes, edited by Cornis-pope, M. and Neubauer, J.

Farrell, K. (1998) Post-traumatic Culture, Injury and Interpretation in the Nineties, Baltimore: The Johns Hopkins University Press.

Felman, S. (2002) The Juridical Unconscious: Trial and Traumas in the Twentieth Century, Cambridge: Harvard University Press.

Freud, S. Remembering, Repeating and Working-Through, Mourning and Melancholia, Beyond the Pleasure Principle, The Standard Edition of the Complete Psychological Works of Sigmund Freud: vols. 12, 14, and 18. Translated by James Strachney (1953) London: Hogarth Press.

Freud, S. (1915/1986) Nesvjesno, Budućnost jedne iluzije, Zagreb: Naprijed.

Freud, S. (1920/1986) S onu stranu načela ugode, Budućnost jedne iluzije, Zagreb: Naprijed.

Friedlander, S. Facing the Shoah: Memory and History, in: Humanity at the Limit: The Impact of the Holocaust Experience on Jews and Christians, ed. Signer, M. A. (2000), Bloomington and Indianapolis: Indiana University Press.

Karas, J. (1985) Music in Terezin 1941-1945, New York: Beaufort.

Kaplan, B. A. (2011) The Holocaust: An „Engorged Symbol of Evil”, Criticism vol.53; Iss. 4, Article 9.

Krstić, P. (2006) Kritička teorija i holokaust, Filozofija i društvo, 1:3777, Beograd: Institut za filozofiju i društvenu teoriju. 
Kuljić, T. (2006) Kultura sećanja: teorijska objašnjenja upotrebe prošlosti, Beograd: Čigoja.

LaCapra, D. (1994) Representing the Holocaust: History, Theory, and Trauma, Ithaca and London: Cornell University Press.

LaCapra, D. (2001) Writing History, Writing Trauma, Baltimore: John Hopkins University Press.

Leys, R. (2000) Trauma: A Genealogy, Chicago: University of Chicago Press.

Niethammer, L. (2000) Kollektive Identität: Heimliche Qellen einer unheimlichen Konjunktur, Reinbek bei Hamburg: Rowohlt Taschenbuch Verlag.

Penderecki, K. (1998) Labyrinth of Time: Five Addresses for the End of the Millenium, Chapel Hill: Hinshaw Music, Inc.

Ray, G. (2005) From Auschwitz to Hiroshima to September 11, New York: Palgrave.

Robinson, R. (1983) Krzysztof Penderecki: A Guide to His Works, Princeton, New Jersey: Prestige Publications, Inc.

Schwinger, W. (1989) Krzysztof Penderecki: His Life and Work, London: Schott \& Co. Ltd.

Ivana Ančić

University of Arts in Belgrade -

Department for the Theory of Arts and Media, Belgrade

\title{
THE ROLE OF ARTS AND HISTORY IN THE REPRESENTATION OF HOLOCAUST
}

\begin{abstract}
Following the famous Adorno's sentence: "Writing poetry after Auschwitz is barbaric", we can ask ourselves if representing holocaust in art is ethical, and if so, what is the proper way of doing it? The Holocaust discourse has motivated and moved many artists and critiques to consider and discuss open questions of holocaust representation. Who has the right to try and represent the holocaust? How should we represent the holocaust and how can we deal with the question of responsibility in a postwar world? Poetry, ritual, music, film, photography, art in general, help us to remember, remind those not yet born that they have to feel suffering they were lucky to avoid, not only as a tribute to the victims, but to stay human. In Auschwitz, culture, science, art and progress became monstrous pictures in the mirror of human existence. A question was raised and constantly repeated after Auschwitz: "Is Auschwitz the end - the peak of our culture or a tipping point that we still do not understand? Is it possible for art to express the truth about Auschwitz?" If holocaust represents a historic turning point for the application of extreme violence of mass killing, then this turning point also presents completely new challenges to individual remembrance and collective memory.
\end{abstract}

Key words: holocaust, trauma, remembrance, memory, art, history 